\title{
WSTĘP REDAKTORÓW TOMU
}

Szanowni Czytelnicy,

w 2018 r. obchodziliśmy setną rocznicę śmierci i 160. rocznicę urodzin Georga Simmla (1858-1918). Spuścizna naukowa genialnego berlińczyka jest jak bezkres oceanu: potężna to siła, gwałtowna, groźna, a zarazem piękna, głęboka i niezmierzona. Zagadnienia, którymi Simmel zajmował się w ciągu swego krótkiego życia, tematy, które podejmował, dyscypliny i nauki, których granice stale przekraczał, dla współczesnych uczonych nauk humanistycznych i społecznych stanowią bogatą bazę i inspirację do prowadzenia własnych badań. Jako Instytut Socjologii Uniwersytetu Kardynała Stefana Wyszyńskiego w Warszawie (UKSW) pragnęliśmy nie tylko wyrazić podziw, nie tylko złożyć hołd jego myśli, ale także podjąć krytyczną debatę na temat aktualnej recepcji Simmla w świecie nauki, zarówno pod względem egzegezy, rozwinięć, jak i polemik oraz krytyk. Ogólnopolska konferencja Georg Simmel. W setna rocznice śmierci mistrza socjologii, zorganizowana 26 września 2018 r. na UKSW, pod auspicjami Polskiego Towarzystwa Socjologicznego oraz Narodowego Centrum Kultury, miała na celu skupienie naukowców, których Simmel ciągle inspiruje i interesuje (sprawozdanie z tego wydarzenia zamieszczamy na s. 67).

Karl Mannheim w eseju pt. Georg Simmel jako filozof o swoim mistrzu i nauczycielu pisze tak: „Był filozofem, ponieważ wielkie dziedzictwo sokratejskie, to zdziwienie nad rzeczami było w nim żywsze niż w każdym innym z jego współczesnych. Jednakże nie wykroczył on poza swój czas, ponieważ przemożny sceptycyzm jego pokolenia był także jego udziałem i swoją wiarą nie zdołał podążać za tym, co zostało mu dane do zobaczenia. Przy czym widział on rzeczy cudowne"1. Sto sześćdziesiąt lat od urodzin i sto lat od śmierci Simmla nie można o nim przestać myśleć, mówić i pisać, nawet jeśli tylko wspominał w swoich pracach o tym, co z daleka ujrzał i czego nie mógł zgłębić. Oczywiście jeden numer czasopisma naukowego nie wyczerpuje tego obszaru badań. Warto dodać, że niezależnie od bieżącego wydania „UCS”, tematyka simmlowska jest przedmiotem pierwszego numeru z 2019 r. „Przeglądu Socjologicznego”, pierwszego polskiego periodyku o stricte socjologicznym profilu, założonego przez nestora polskiej socjologii Floriana Znanieckiego. Możliwość zaprezentowania tej tematyki w różnych czasopismach stanowi doskonałą okazję do wzajemnego dopełnienia i ukazania jej w perspektywie panoramicznej - teksty zostały ocenione przez dwie redakcje oraz dwa niezależne zespoły recenzentów, co znacząco wpływa na ich jakość.

Treści zaprezentowane w niniejszym tomie „UCS” to w dużej mierze wynik analiz współczesnych zjawisk społecznych, uwzględniających perspektywę simmlowską. Składa się na niego sześć artykułów naukowych.

Dariusz Prokopowicz w opracowaniu Geneza i konsekwencje globalnego kryzysu finansowego 2008 roku. Simmlowskie inspiracje dowodzi aktualności rozpoznań filozofa przełomu XIX i XX w. dotyczących ekonomii i ich znaczenia w kontekście analizy przyczyn załamania na rynkach finansowych z początku XXI w. Według autora artykułu w Filozofi pieniądza, jednej z najbardziej znanych prac niemieckiego myśliciela, można odnaleźć kluczowe tezy współczesnej etyki biznesowej i społecznej odpowiedzialności biznesu, co z kolei wskazuje na nowatorskość myśli Simmla. W opracowaniu ukazano powiązania między procesami i relacjami socjoekonomicznymi a systemem finansowym czy polityką monetarną, które oddziałują na siebie, będąc elementami globalnego rynku wymiany. Autor ostrzega przed bezrefleksyjnym dążeniem do

1 K. Mannheim (1985), Georg Simmel als Philosoph [w:] É. Vezér, E. Vezér (Hrsg.), Georg Lukás, Karl Mannheim und der Sonntagskreis. Frankfurt am Main: Sendler, s. 150. 
zniesienia mechanizmów kontrolnych w gospodarce, uważając, że takie działanie nie jest korzystne w optyce bezpieczeństwa kredytowego oraz sprzedaży innych produktów bankowych. Podkreśla, że „wtórnym efektem istnienia wielu czynników systemowego ryzyka kredytowego jest wątpliwa stabilność systemów finansowych i możliwość pojawienia się podobnych kryzysów w przyszłości”, potwierdzając tym samym współczesną niespójność i kontradykcyjność kapitalizmu, którego funkcjonalność ulega stopniowej erozji.

W artykule Wstronę kultury materialnej. Zarządzanie ryzykiem w dobie późnej nowoczesności Jordan Klimek dokonał analizy kondycji społeczeństwa polskiego w nawiązaniu do Simmlowskich rozważań nad kulturą materialną oraz indywidualną. Autor odwołuje się do redukcjonizmu pieniężnego, który obejmuje większość współczesnych wartości, nawiązując przy tym do tez sformułowanych w Filozofii pieniądza. Podkreśla również istotną rolę technologii informacyjnych w kształtowaniu się ekonomii i innych aspektów życia społecznego, takich jak towary utożsamiane z tworzeniem wyobrażeń na temat jaźni oraz tożsamości. W opracowaniu zweryfikowano tezy o wzroście kultury materialnej w ujęciu Simmla, podnosząc aktualność tej problematyki we współczesnych analizach socjologicznych. Poruszono także kwestie wartości moralnej zaufania między ludźmi, odwołując się do jego zasadności i przypominając o promowanej przez Simmla postawie otwartości i ufności, na której można budować kompleksowe systemy ekonomiczne.

Artykuł pt. Cztowieczeństwo, sprawczość i troska transcendentna autorstwa ks. Artura Wysockiego stanowi ważny głos w dyskusji na temat człowieczeństwa w optyce socjologicznej, zwłaszcza w odniesieniu do klasycznych stwierdzeń „filozofii życia” Simmla oraz współczesnego dorobku Margaret S. Archer i w kontekście relacyjnej natury człowieka. Celem tego artykułu jest rozważenie zasadności włączenia troski transcendentnej do zestawu trosk podstawowych w życiu człowieka według koncepcji Archer. Autor opisuje podstawowe wymiary ujętej w tytule tematyki i twórczo je rozwija, odnosząc się do takich dymensji, jak np. troska transcendentna, sprawstwo i relacje między troskami. Co ważne, podejmuje on zagadnienia, które ulokowane są na pograniczu religii i społeczeństwa, ukazując aktualność koncepcji badawczych w tym zakresie, a także użyteczność klasycznych tekstów Simmlowskich.

Anna Pasek porusza istotny temat z zakresu problematyki relacji społecznych, a mianowicie kwestię zaufania. Opracowanie zatytułowane Pojęcie zaufania $w$ spoteczeństwie nowoczesnym $i$ ponowoczesnym jest próbą syntezy ukazania tej kategorii w pracach różnych autorów na przestrzeni lat oraz zmian w jego konceptualizacji i operacjonalizacji.

Artykuł Praca i bezrobocie - uwarunkowania psychospoteczne. Analiza zjawisk w lokalnej odstonie opiera się na analizie badawczej danych pochodzących ze źródeł statystyki publicznej, mocno osadzonej w teorii socjologicznej, w tym również odnoszącej się do dorobku Simmla. Autorzy komunikatu z badań - Paweł Prüfer oraz Bernadeta Piszczygłowa - zaprezentowali pojęcie zatrudnienia przez szereg dymensji (takich jak stopa i skala bezrobocia, kategorialność zawodowa bezrobotnych oraz poradnictwo pracy czy możliwości zatrudnienia). Wymiary te pozwoliły na uchwycenie dynamiki pracy i bezrobocia w Gorzowie Wielkopolskim. Niewątpliwym atutem tego opracowania jest jego aktualność, ukazująca głębokie przemiany na lokalnym rynku pracy.

Hazard jako fakt spoteczny (wspótczesne odstony) to temat debiutanckiego opracowania Marty Gontarz. Autorka przybliża wymiary uzależnienia behawioralnego (czynnościowego), jakim jest hazard, w optyce makrospołecznej (w wymiarach dysfunkcjonalności, dezintegracji i dewiacji). To dojrzała analiza teoretyczno-empiryczna, oparta m.in. na wynikach badań CBOS, która prezentuje stanowisko klasycznej socjologii, odwołując się do myśli Emila Durkheima, Floriana Znanieckiego i Simmla, a także jej obecnych kontynuatorów.

W dziale recenzji zamieszczamy opinię Agnieszki Zduniak na temat najnowszej książki wybitnego nestora polskiej socjologii religii - Janusza Mariańskiego - zatytułowanej Nowa religijność i duchowość - mit czy rzeczywistość? Studium socjologiczne. Publikacja została wydana w prężnie rozwijającej się oficynie - Warszawskim Wydawnictwie Socjologicznym, które oferuje coraz więcej tytułów prezentujących najnowsze obserwacje z dziedziny nauk społecznych, zarówno w formie monograficznej, jak i prac zbiorowych. Autorka odnosi się szczegółowo do treści zaprezentowanych w rozdziałach recenzowanej pracy, dokonując ich trafnej syntezy. W jej opinii studium „zawiera propozycje odpowiedzi na wiele ważnych pytań współczesnej socjologii duchowości, prowadzi przez gąszcz terminologii i koncepcji teoretycznych, wskazuje możliwe i ważne kierunki poszukiwań. Jednocześnie czyni to w sposób wyważony, nie narzucając gotowych rozwiązań, pobudzając do 
refleksji i poszukiwania nowych kierunków eksplorowania złożonego, ale bardzo interesującego zjawiska”. Dowodzi to tym samym rzetelności naukowej tego dzieła, tak bardzo pożądanego na naukowym rynku wydawniczym.

Opracowania naukowe zawarte w niniejszym numerze „UCS” są odzwierciedleniem przyjętego założenia tematycznego oraz jego ujęć we współczesnych analizach polskich socjologów. Co ważne, ujawniają niezwykłą aktualność koncepcji Simmla i ich nowatorskość, wykraczającą poza samą socjologię, a także przełamującą ramy czasowe.

Tomasz M. Korczyński i Marcin Choczyński 